\title{
UPAYA PENINGKATAN KETERAMPILAN SOSIAL DALAM EKOLITERASI KETAHANAN HAYATI MELALUI PEMBELAJARAN KOOPERATIF TIPE KELOMPOK INVESTIGASI PADA MAHASISWA PENDIDIKAN BIOLOGI SEMESTER III TAHUN AKADEMIK 2008/2009
}

\author{
Ni Wayan Ekayanti, Dewa Ayu Puspawati, Sang Putu Kaler Surata \\ Program Studi Pendidikan Biologi, Fakultas Keguruan dan Ilmu Pendidikan, \\ Universitas Mahasaraswati Denpasar
}

\begin{abstract}
Environmental damage that has occurred recently, caused a various biosecurity problems. However, the people knowledge, understanding and awareness about these are still low. The ecoliteracy is a strategic approach for enggaging young generation in manage biosecurity issues. The purpose of this study is to evaluate how far undergraduate teacher training students able to increase their social skill, as one important aspect for successful management of biosecurity, after following biosecurity ecoliteracy. It was excecuted through class action research toward 30 undergraduate students of Biology Education Department, University of Mahasaraswati Denpasar. They followed indoor and outdoor learning based on cooperative learning approach and group investigation techniques nearly two month (August-September 2009), with twice face to face interaction in a week. Their behavior were observed using a rubric with four Likert Scalle, and data was analyzed with z-test. Nearly all components social skill of students were increasing significantly: contribution to group objectives $(P=0.000)$, contribution to group knowledge $(P=0.000)$, and sharing ideas $(P=0.000)$. These showed that cooperative learning and group investigation are strongly tool for encouraging social skill in biosecurity ecoliteracy.
\end{abstract}

Keywords:cooperative learning, encouraging, social skill, biosecurity ecoliteracy.

\section{PENDAHULUAN}

Kerusakan lingkungan yang terjadi dalam dasa warsa belakangan ini telah mengakibatkan terjadinya invasi hayati oleh spesies asing yang menyebabkan terjadinya kerusakan dan mempunyai pengaruh yang sangat besar pada ketahanan hayati (biosecurity). Terjadinya hal tersebut harus diimbangi dengan respon dari masyarakat terhadap ketahanan hayati, dengan cara memperkuat kapasitas hayati, namun sayangnya, respon terhadap ketahanan hayati dan keanekaragaman hayati (biodiversity) dari masyarakat luas masih sangat rendah.

Salah satu strategi yang dapat dikembangkan dalam mengantisipasi ketahanan hayati adalah dengan melibatkan masyarakat luas yaitu dengan memperbaiki pemahaman dan kesadaran mengenai pentingnya menjaga ketahanan hayati. Salah satu strategi untuk memperkuat kapasitas ketahanan hayati generasi muda mengenai interaksi antara masalah 
ekologi dan sosial serta kemampuan untuk mengelola isu-isu ketahanan hayati adalah melalui literasi ekologi sosial yang dapat diterapkan pada pendidikan formal (Surata $d k k, 2009$ ). Pendidikan formal yang diacu terkait dengan isu ketahanan hayati serta keanekaragaman hayati adalah pendidikan formal diperguruan tinggi, dimana dalam hal ini, mahasiswa mulai dilibatkan dalam kegiatan ini. Proses pembelajaran ini menyediakan kesempatan unik bagi mahasiswa pendidikan biologi untuk belajar mengenai struktur, isi dan proses pendidikan ketahanan hayati, sehingga nantinya memiliki kompetensi dalam memfasilitasi mekanisme pembelajaran yang transformatif berbasis konsep belajar sebagai proses sosial. Diharapakan dengan pembelajaran ekoliterasi ini mahasiswa sadar dengan pentingnya menjaga kelestarian lingkungan dan nantinya kesadaran itu bisa ditularkan pada masyarakat luas. Namun hal tersebut tidak akan bisa tercapai bila aspek sosial mahasiswa masih rendah. Untuk meningkatkan aspek sosial mahasiswa dapat dilakukan dengan melakukan pembelajaran kooperatif.

Kegiatan pembelajaran ekoliterasi yang berbasis pembelajaran kooperatif tipe kelompok investigasi yaitu yaitu pembelajaran dalam kelompok dimana anggota dalam kelompok tersebut akan bekerjasama untuk mencapai tujuan dari kelompok tersebut (Alma $d k k$, 2009). Dengan adanya kolaborasi anggota dalam kelompok dalam kegiatan pembelajaran ini akan mampu memperkuat aset sosial mahasiswa pendidikan biologi yaitu mendorong mahasiswa untuk mengembangkan mekanisme pembelajaran transformatif yang mampu meningkatkan kemitraan, kerjasama dan kolaborasi, baik dengan komunitas di dalam maupun di luar ruang kelas (Lie, 2002).

Lemahnya aspek sosial pada mahasiswa pendidikan biologi semester III FKIP Universitas Mahasaraswati Denpasar tahun akademik 2008/2009, seperti keterampilan sosial, berkomunikasi sesama anggota kelompok, dan kurangnya kepercayaan terhadap anggota kelompok mengakibatkan hasil belajar yang tidak merata pada setiap anggota kelompok. Hal ini bisa diperbaiki dengan pembelajaran kooperatif tipe kelompok investigasi (Group Investigation) yang selanjutnya disebut GI, dimana semua anggota kelompok harus bekerja sama untuk mencapai tujuan kelompok. Yang menjadi inti permasalahan yang ingin dipecahkan yaitu Apakah dengan penerapan model pembelajaran kooperatif tipe GI dalam pembelajaran ekoliterasi pada mahasiswa pendidikan biologi semester III FKIP Universitas Mahasaraswati Denpasar tahun akademik 2008/2009 dapat meningkatkan perilaku anggota dalam kelompok dan perilaku berkelompok? Dan bagaimanakah kecenderungan penilaian yang diberikan oleh fasilitator, dan teman sebaya terhadap perilaku anggota dalam kelompok serta perilaku berkelompok dalam pembelajaran ekoliterasi? 
Tujuan dari penelitian tindakan kelas ini adalah untuk membandingkan peningkatan prilaku anggota dalam kelompok dan perilaku berkelompok dari siklus I dengan siklus II pada mahasiswa pada mahasiswa pendidikan biologi semester III FKIP Universitas Mahasaraswati Denpasar tahun akademik 2008/2009 dengan penerapan pembelajaran ekoliterasi berbasis pembelajaran kooperatif tipe GI dan membandingkan kecenderungan penilaian terhadap penilaian perilaku anggota dalam kelompok dan perilaku berkelompok yang dinilai oleh fasilitator, dan teman sebaya.

\section{Metode Penelitian}

Penelitian Tindakan Kelas merupakan suatu pencermatan terhadap kegiatan belajar berupa sebuah tindakan, yang sengaja dimunculkan dan terjadi dalam sebuah kelas secara bersama (Arikunto, 2002). Metode pembelajaran dalam penelitian ini adalah pembelajaran kooperatif tipe GI yang diterapkan pada mata kuliah ekoliterasi ketahanan hayati pada mahasiswa pendidikan biologi semester III FKIP Universitas Mahasaraswati Denpasar tahun akademik 2008/2009. Penelitian ini dilaksanakan di kampus Universitas Mahasaraswati Denpasar, jalan Soka Denpasar Timur, mulai bulan Agustus 2009 sampai dengan bulan September 2009. Subjek penelitian ini adalah mahasiswa pendidikan biologi program studi biologi semester III FKIP Universitas Mahasaraswati Denpasar Tahun Akademik 2008/2009 sebanyak 30 orang. Objek Penelitian ini adalah perilaku anggota dalam kelompok dan perilaku berkelompok mahasiswa.

Data yang dikumpulkan dalam penelitian ini adalah data perilaku anggota dalam kelompok dan perilaku berkelompok. Data .tersebut .diperoleh .dengan .penyebaran. rubrik penilaian. yang disiapkan oleh Surata $d k k$ (2009) pada kelompok penilai yang meliputi penilaian oleh fasilitator dan penilaian oleh teman sebaya. Dalam tiap lembar penilaian rubrik penilaian dilakukan dengan memberikan nilai sesuai dengan kriteria, seperti baik dengan nilai 4, sedang dengan nilai 3, cukup dengan nilai 2 dan kurang dengan nilai 1 . Kedua data dianalisis dengan uji two related samples-test menggunakan SPSS seri 16. Lalu data dari fasilitator dan teman sebaya dibandingkan pada masing-masing katagori untuk diketahui apakah ada perbedaan atau tidak.

\section{HASIL DAN PEMBAHASAN}


Perilaku Anggota dalam Kelompok: Pada penelitian perilaku anggota dalam kelompok ada empat aspek sosial yang dinilai yaitu Kontribusi Terhadap Tujuan Kelompok (KTK), Tenggangrasa Terhadap Anggota Kelompok (TRS), Kontribusi Terhadap Pengetahuan Kelompok (KTP), Bekerja dan Berbagi dengan Anggota yang lain (BBA). Untuk mengetahui apakah ada perbedaan antara siklus I dengan siklus II maka dilakukan pembandingan mengenai aspek sosial mahasiswa pendidikan biologi. Dari aspek sosial yang dinilai, semua mengalami peningkatan. Data siklus I dan Siklus II kemudian dibandingkan seperti pada Tabel 1 berikut ini:

Tabel 1. Perbandingan Penilaian Keterampilan Sosial Prilaku Anggota dalam Kelompok

\begin{tabular}{|c|c|c|c|c|c|c|c|c|c|c|}
\hline \multirow[t]{2}{*}{ NAMA } & \multicolumn{5}{|c|}{ SIKLUS I } & \multicolumn{5}{|c|}{ SIKLUS II } \\
\hline & KTK & TRS & KTP & $\mathrm{BBA}$ & Rataan & KTK & TRS & KTP & $\mathrm{BBA}$ & Rataan \\
\hline Adi Martono & 3,00 & 2,87 & 2,87 & 3,12 & 2,96 & 3,66 & 3,66 & 3,50 & 3,66 & 3,62 \\
\hline Agung Paramita & 3,25 & 3,50 & 3,37 & 3,50 & 3,40 & 4,00 & 4,00 & 4,00 & 4,00 & 4,00 \\
\hline Agus Saputra & 3,00 & 2,50 & 2,50 & 2,75 & 2,68 & 3,00 & 3,66 & 2,83 & 3,66 & 3,28 \\
\hline Albinus Kaha & 2,87 & 2,75 & 2,37 & 2,75 & 1,99 & 3,50 & 2,83 & 3,33 & 3,50 & 3,11 \\
\hline Antarawati & 3,62 & 3,62 & 3,37 & 3,75 & 3,59 & 4,00 & 3,38 & 4,00 & 3,38 & 3,69 \\
\hline Ari Sanjaya & 3,25 & 3,25 & 3,50 & 3,25 & 3,31 & 3,38 & 3,33 & 3,66 & 3,38 & 3,43 \\
\hline Artini & 2,75 & 2,87 & 2,50 & 3,00 & 2,78 & 3,33 & 3,49 & 3,00 & 3,65 & 3,36 \\
\hline Darmayasa & 3,12 & 3,37 & 3,12 & 3,25 & 3,12 & 4,00 & 4,00 & 4,00 & 4,00 & 4,00 \\
\hline Dewi Puspita Sari & 2,75 & 3,00 & 2,50 & 3,25 & 2,87 & 3,50 & 3,66 & 3,66 & 3,50 & 3,58 \\
\hline Gangga Yamuni & 3,62 & 3,50 & 3,50 & 3,37 & 3,49 & 4,00 & 3,38 & 3,50 & 3,50 & 3,59 \\
\hline Gerson & 2.50 & 2,50 & 1,87 & 2,75 & 2,40 & 3,00 & 3,50 & 2,66 & 3,50 & 3,16 \\
\hline Hadi Saputra & 3,37 & 3,37 & 3,25 & 3,12 & 3,27 & 3,33 & 3,00 & 3,16 & 3,33 & 3,20 \\
\hline Handari & 3,00 & 3,50 & 3,00 & 3,50 & 3,25 & 3,38 & 3,66 & 3,50 & 3,38 & 3,48 \\
\hline IG Pradipta & 2,87 & 2,87 & 2,87 & 3,12 & 2,93 & 3,66 & 3,50 & 4,00 & 3,65 & 3,70 \\
\hline Ilia Eprina & 3,37 & 3,00 & 2,87 & 2,75 & 2,99 & 3,75 & 3,00 & 3,00 & 4,00 & 3,43 \\
\hline Jeni hariyati & 3,75 & 3,50 & 3,87 & 3,37 & 2,78 & 3,38 & 4,00 & 3,38 & 4,00 & 3,69 \\
\hline Kardiasari & 3,25 & 3,50 & 3,62 & 3,37 & 3,43 & 3,50 & 3,66 & 3,38 & 3,50 & 3,51 \\
\hline Lidya astuti & 2,87 & 3,00 & 2,50 & 2,62 & 2,74 & 3,33 & 3,16 & 3,00 & 4,00 & 3,37 \\
\hline Nata Wibawa & 2,62 & 3,00 & 3,00 & 2,75 & 2,84 & 3,66 & 3,16 & 3,16 & 4,00 & 3,49 \\
\hline Nopi Ayu Apsari & 2,75 & 2,87 & 2,25 & 2,87 & 2,68 & 3,00 & 3,25 & 3,00 & 3,25 & 3,12 \\
\hline Oktavianus Ardis & 2,87 & 2,75 & 2,87 & 2,62 & 2,77 & 3,38 & 3,33 & 3,15 & 4,00 & 3,46 \\
\hline Parwati & 2,75 & 2,87 & 2,62 & 2,50 & 2,68 & 3,33 & 3,33 & 3,00 & 3,38 & 3,26 \\
\hline Purnama Sari & 3,12 & 3,25 & 3,37 & 3,37 & 3,27 & 3,66 & 3,31 & 3,66 & 4,00 & 3,65 \\
\hline Putri Indriani & 3,25 & 3,12 & 3,62 & 3,00 & 3,24 & 3,38 & 3,33 & 3,66 & 3,38 & 3,43 \\
\hline Suandewi & 3,87 & 3,50 & 2,87 & 3,50 & 3,43 & 4,00 & 4,00 & 4,00 & 4,00 & 4,00 \\
\hline Sugiartini & 3,00 & 3,00 & 3,12 & 3,12 & 3,06 & 3,33 & 3,16 & 3,16 & 3,50 & 3,28 \\
\hline Sumartini & 2,75 & 2,50 & 2,75 & 2,75 & 2,68 & 3,16 & 3,15 & 3,00 & 3,48 & 3,19 \\
\hline Titin Cahayaningrum & 3,12 & 3,00 & 3,37 & 3,50 & 3,24 & 3,33 & 3,50 & 3,16 & 3,33 & 3,33 \\
\hline Valeriana Kumiati & 3,62 & 3,25 & 3,25 & 3,00 & 3,28 & 3,33 & 3,33 & 3,16 & 3,33 & 3,28 \\
\hline Visensius Mali & 2,00 & 2,25 & 1,75 & 2,00 & 2,00 & 2,75 & 3,75 & 2,50 & 3,50 & 3,12 \\
\hline Rataan & 3,06 & 3,06 & 2,94 & 3,05 & 2,97 & 3,46 & 3,44 & 3,39 & 3,62 & 3,46 \\
\hline Simpangan Baku & 0,40 & 0,36 & 0,51 & 0,38 & 0,40 & 0,32 & 0,31 & 0,41 & 0,26 & 0,24 \\
\hline
\end{tabular}

Keterangan: KTK (kontribusi terhadap tujuan kelompok), TRS (tenggangrasa terhadap anggota kelompok), KTP (Kontribusi terhadap pengetahuan kelompok), BBA (Bekerja dan berbagi dengan anggota yang lain)

Terjadi peningkatan yang sangat berbeda nyata dari hasil penilaian yang telah dilakukan dari siklus I ke siklus II, hal tersebut terlihat dari hasil uji two related samples test 
yang telah dilakukan didapatkan tingkat signifikansi $(0,000)$ yang berarti bahwa ada perbedaan nyata antara siklus I dengan siklus II, yang menunjukkan bahwa aspek sosial mahasiswa meningkat. Hal itu berarti terjadi peningkatan perilaku anggota dalam kelompok dalam pembelajaran ekoliterasi berbasis pembelajaran kooperatif tipe GI bagi mahasiswa pendidikan biologi semester III FKIP Universitas Mahasaraswati Denpasar tahun akademik 2008/2009. Semua aspek sosial yang dinilai dalam pembelajaran kooperatif tipe GI pada mata kuliah Ekoliterasi Ketahanan Hayati mengalami peningkatan. Peningkatan aspek sosial itu sesuai dengan hasil penelitian Susilaningsih (2009) yang menunjukkan bahwa pembelajaran tipe GI dapat meningkatkan kemampuan siswa menjawab soal secara langsung dan prestasi belajar siswa lebih dari 50\%. Peningkatan aspek-aspek sosial yang dinilai dalam penelitian ini sangat terkait dengan metode pembelajaran kooperatif yang telah berlangsung, monitoring serta refleksi yang diberikan oleh fasilitator, teman sebaya dan oleh mahasiswa sendiri.

Dari penilaian yang diberikan oleh teman sebaya dan fasilitator terlihat adanya perbedaan, dimana penilaian yang diberikan oleh fasilitator cenderung lebih tinggi dari pada penilaian yang diberikan oleh teman sebaya. Perbandingan hasil penilaian Fasilitator dengan Teman Sebaya pada siklus I dan II dapat dilihat pada Gambar 1:

Hasil uji-Z menunjukkan bahwa ada perbedaan nyata antara penilaian yang diberikan oleh Teman Sebaya bila dibandingkan dengan penilaian yang diberikan oleh Fasilitator $\left(Z_{30}=-3,199 ; P=0,001\right)$. Penilaian oleh Fasilitator cenderung lebih tinggi dari pada penilaian yang diberikan oleh Teman Sebaya. Perbedaan tersebut dapat terjadi karena penilaian dilakukan oleh beberapa penilai. Penilaian yang diberikan dapat berbeda dari satu penilai dengan penilai yang lain karena faktor-faktor lain misalnya umur, wawasan, pengalaman dan kecenderungan sosial penilai (Nuryani, 2006). Karena antara Fasilitator dan Teman Sebaya memiliki kemampuan, wawasan serta pengalaman yang berbeda dalam pembelajaran, tentu perbedaan kecenderungan penilaian tersebut bisa terjadi. Hal tersebut berarti ada ketidaksamaan persepsi antara kedua kelompok penilai sehingga kecenderungan penilaian yang diberikan oleh kedua kelompok penilai sangat berbeda nyata. Persepsi penilaian perlu disamakan sebelum dilakukan penelitian, agar kecenderungan penilaian yang diberikan tidak terlalu jauh berbeda. 


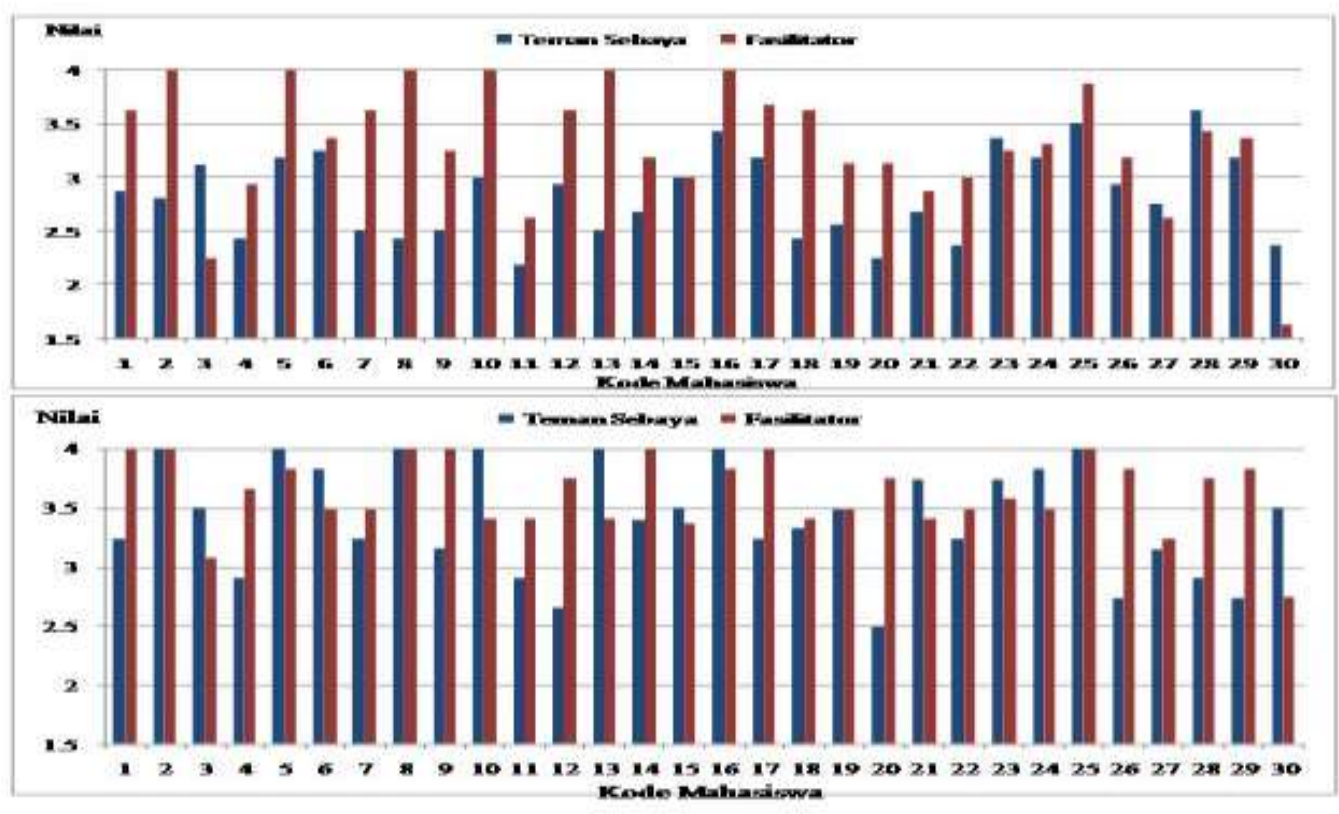

Gambar 1. Perbandingan Penilaian Aspek Sosial Prilaku Anggota dalam Kelompok antara Siklus I dengan Siklus II oleh Teman Sebaya dan Fasilitator dalam Pembelajaran Ekoliterasi Ketahanan Hayati Berbasis Pembelajaran Kooperatif Tipe GI. Nama Mahasiswa: (1=Adi Martono, 2=Agung Paramita, 3=Agus Saputra, 4=Albinus Kaha, 5=Antarawati, 6=Ari Sanjaya, 7=Artini, 8=Darmayasa, 9=Dewi Puspitasari, 10=Gangga Yamuni, 11=Gerson, 12=Hadi Saputra, 13=Handari, 14=IG Pradipta, 15=Ilia Eprina, 16=Jeni Hariyati, 17=Kardiasari, 18=Lidya Astuti, 19=Nata Wibawa, 20=Nopi Ayu Apsari, 21=Oktavianus Ardis, 22=Parwati, 23=Purnama Sari, 24=Putri Indriani, 25=Suandewi, 26=Sugiartini, 27=Sumartini, 28=Titin Cahyaningrum, 29=Valeriana Kumiati, 30=Vinsensius Mali). Skor: 4(Baik), 3(Sedang), 2(Cukup), 1(Kurang). A=Siklus I, B=Siklus II

Perilaku Berkelompok: Untuk prilaku berkelompok ada empat aspek sosial yang diamati yaitu PK, PTB, KI, dan PDAK. Prilaku berkelompok dinilai dari dua sisi yaitu dari segi masing-masing aspek sosial mahasiswa dan dari kecenderungan penilaian yang diberikan oleh kelompok penilai yaitu, teman sebaya serta fasilitator. Penilaian dari aspek sosial mahasiswa dapat dilihat pada Tabel 2. Terlihat bahwa rentang nilai masing-masing aspek sosial kelompok dari siklus I ke siklus II tidak terlalu jauh. Hal tersebut diperkuat oleh hasil uji-Z yang menunjukkan tidak adanya perbedaan nyata antara siklus I dengan siklus II pada masing-masing aspek sosial kelompok. Hal itu berarti bahwa memang terjadi peningkatan dari siklus I ke siklus II namun tidak dengan perbedaan yang nyata. Artinya, penilaian yang diberikan oleh kelompok penilai untuk Prilaku Berkelompok pada siklus I hampir sama dengan penilaian yang diberikan pada siklus II. Terlihat dari penilaian oleh penilai cukup tinggi, hal itu cenderung diakibatkan karena mahasiswa Pendidikan Biologi semester III tahun akademik 2008/2009 telah melakukan pembelajaran kooperatif tipe jigsaw dalam mata kuliah pengetahuan lingkungan yang secara nyata telah dapat meningkatkan aktivitas dan prestasi belajar mahasiswa calon guru Universitas Mahasaraswati Denpasar (Suadiani, 2009). 
Tabel 2. Perbandingan Penilaian Keterampilan Sosial Prilaku Berkelompok, antara siklus 1 dan siklus 2

\begin{tabular}{ccccccccccc}
\hline Kelompok & \multicolumn{9}{c}{ Siklus I } & \multicolumn{5}{c}{ Siklus II } \\
& PK & PTB & KI & PADK & Rataan & PK & PTB & KI & PADK & Rataan \\
\hline A & 3,91 & 3,83 & 3,66 & 3,83 & 3,80 & 4,00 & 4,00 & 3,77 & 4,00 & 3,94 \\
B & 3,25 & 3,33 & 2,75 & 3,00 & 3,08 & 3,33 & 3,55 & 2,83 & 3,11 & 3,20 \\
C & 3,41 & 3,83 & 3,16 & 3,66 & 3,51 & 3,72 & 3,83 & 3,56 & 3,73 & 3,71 \\
D & 3,41 & 3,58 & 3,08 & 3,33 & 3,35 & 3,72 & 2,33 & 3,00 & 4,00 & 3,26 \\
E & 2,83 & 2,83 & 3,00 & 2,66 & 2,83 & 3,33 & 3,55 & 2,99 & 2,88 & 3,18 \\
F & 3,50 & 3,41 & 3,33 & 3,25 & 3,37 & 3,27 & 3,66 & 3,22 & 3,00 & 3,28 \\
\hline Rataan & 3,38 & 3,46 & 3,16 & 3,28 & 3,32 & 3,56 & 3,48 & 3,22 & 3,45 & 3,42 \\
\hline Simpangan & & & & & & & & & & \\
baku & 0,35 & 0,37 & 0,30 & 0,42 & 0,33 & 0,29 & 0,59 & 0,36 & 0,51 & 0,31 \\
\hline
\end{tabular}

Keterangan : Partisipasi Kelompok (PK), Pembagian Tanggungjawab (PTB), Kualitas interaksi (KI), Peranan Anggota dalam Kelompok (PADK).

Bila dibandingkan kecenderungan penilaian yang diberikan oleh kedua kelompok penilai tidak memiliki rentang yang terlalu jauh. Jika ditinjau dari masing-masing kelompok penilai maka penilai cenderung memiliki penilaian bahwa prilaku berkelompok mengalami peningkatan dari siklus I jika dibandingkan dengan siklus II. Penilaian dari kelompok penilai terhadap prilaku berkelompok dapat dilihat pada Gambar 2
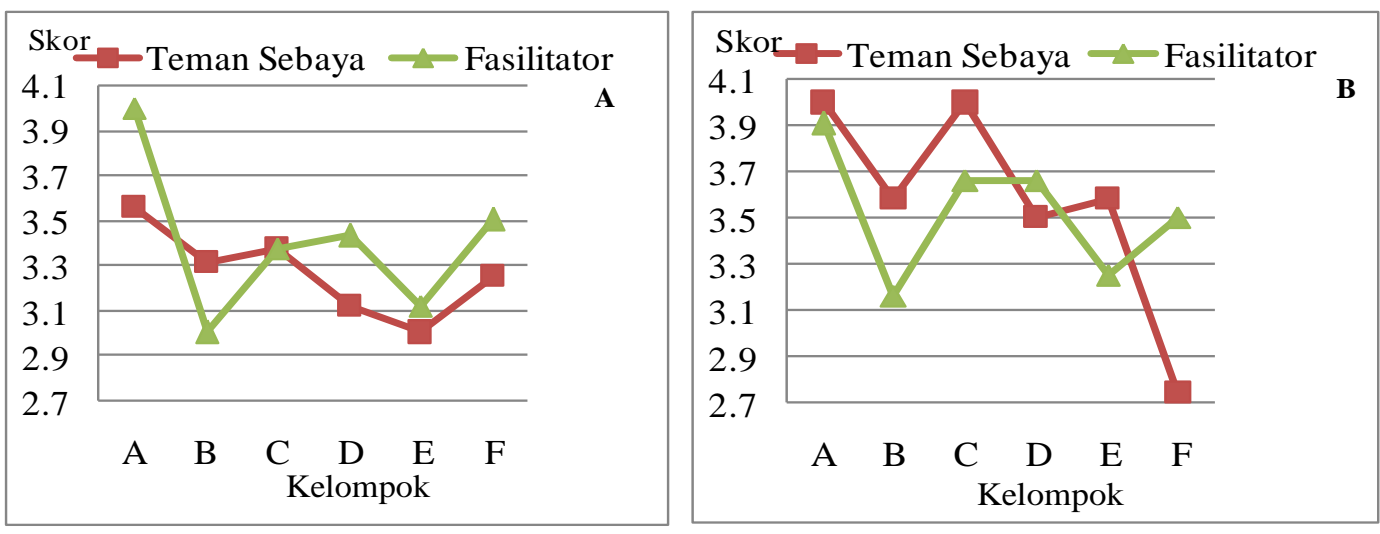

Gambar 4. Perbandingan Prilaku Berkelompok dari Siklus I (A) ke Siklus II (B), ditinjau dari Kecenderungan Penilaian yang Diberikan oleh Kelompok Penilai.

Jika penilaian antar kelompok penilai dibandingkan, tidak ada rentang penilaian yang terlalu jauh berbeda, hal tersebut terjadi pada siklus I maupun siklus II. Penilaian yang diberikan oleh teman sebaya cenderung sama dengan penilaian yang berikan oleh fasilitator. Pada Gambar 2 terlihat tidak ada perbedaan yang nyata antara nilai yang diberikan oleh teman sebaya dan fasilitator. Hasil uji- $Z$ menunjukkan bahwa tidak ada perbedaan nyata antara penilaian terhadap prilaku kelompok yang berikan oleh teman sebaya jika dibandingkan dengan penilaian yang diberikan oleh fasilitator $\left(Z_{6}=-0,420 ; P=0,674\right)$. 
Yang berarti bahwa penilaian yang diberikan oleh teman sebaya dan fasilitator hampir sama. Itu berarti antara teman sebaya dan fasilitator memiliki persepsi yang sama mengenai Prilaku Berkelompok yang terjadi dalam kuliah Ekoliterasi Ketahanan Hayati.

\section{SIMPULAN}

Pembelajaran kooperatif tipe GI pada mata kuliah ekologi ketahanan hayati dapat keterampilan sosial (dalam bentuk perilaku anggota dalam kelompok dan perilaku berkelompok) mahasiswa pendidikan biologi semester III FKIP Universitas Mahasaraswati Denpasar tahun akademik 2008/2009. Ada kecenderungan penilaian yang diberikan oleh teman sebaya dan fasilitator berbeda nyata pada perilaku anggota dalam kelompok, namun tidak berbeda nyata untuk perilaku berkelompok.

\section{UCAPAN TERIMAKASIH}

Data yang diperoleh dalam penelitian ini merupakan sebagian data yang diperoleh dalam Hasil Penelitian Hibah Strategis Nasional Direktur Jenderal Pendidikan Tinggi Kementerian Pendidikan Nasional, tahun 2009. Penulis mengucapkan terima kasih pada Mahasiswa Pendidikan Biologi FKIP Unmas Denpasar, semester III tahun akademik 2008/2009 yang telah berpartisipasi aktif, baik sebagai subjek maupun objek penelitian

\section{DAFTAR PUSTAKA}

Alma B, Mulyadi H, Razati G \& Nuryati L. 2009. Guru Profesional Menguasai Metode dan Terampil Mengajar. Bandung: Alfabeta

Arikunto S. 2002. Dasar-dasar Evaluasi Pendidikan. Jakarta: Bumi Aksara

Lie A. 2002. Cooperative Learning. Jakarta: PT Gramedia. Cet. Ke-5

Nuryani. 2006. Trend Penilaian Pembelajaran IPA.

http://bullah10.blogspot.com/2009/06/trend-penilaian-pembelajaran-ipa-masa.html. Diakses 12 November 2009

Suadiani NW. 2009. Upaya Meningkatkan Prestasi Belajar Siswa Melalui Metode Pembelajaran Kooperatif Tipe Jigsaw pada Mata Kuliah Pengetahuan Lingkungan untuk Mahasiswa Calon Guru. Skripsi (S1) Jurusan Pendidikan Biologi Universitas Mahasaraswati Denpasar

Surata SPK,Vipriyanti KU \& Martiningsih AAGE. 2009. Pendekatan Artistik dalam Pendidikan Ketahanan Hayati: Pengembangan Model Literasi Ekologi-Sosial bagi Mahasiswa calon Guru. Hibah Penelitian UNMAS. Tidak diterbitkan

Susilaningsih A. 2009. Penerapan Pembelajaran Kooperatif Model Group Investigation (GI) Dalam Upaya Meningkatkan Kemampuan Procedural Fluency Siswa (PTK Pembelajaran Matematika di Kelas VII SMP Muhammadiyah 4 Surakarta). Skripsi thesis, Universitas Muhammadiyah Surakarta . http://etd.eprints.ums.ac.id/4811/. Diunduh 3 Juni 2010 
